\title{
Neovascular Complications Revealing Anguloid Streaks in Pseudoxanthoma Elasticum
}

\section{Kawtar Zaoui*}

Mohamed V Military Teaching Hospital - Mohamed V University Rabat, Morocco

Submission: June 19, 2020; Published: July 27, 2020

*Corresponding author: Kawtar Zaoui, Mohamed V Military Teaching Hospital, Hay Ryad, Mohamed v university Rabat, Morocco

\section{Abstract}

35-year-old woman previously healthy, who consults for a rapidly progressive bilateral visual acuity drop more accentuated on the left eye quantified at $2 / 10$, while the value was $5 / 10$ for the right eye. The ophthalmological examination of the anterior segment was normal. The fundus examination (Figure 1) showed: anguloid streaks appear as narrow, lines extending from the papilla towards the retinal periphery, with temporal perifoveolar streaks on the right eye and foveolar ones on the left. Macular OCT (Figure 2): objectified bilateral subretinal hyperreflectivity corresponding to a fibrovascular scar. On the left eye there is macular lamellar clarity. No exudative sign on the right eye (Figure 3-5).

Keywords: Anterior segment; Anguloid streaks; Papilla; Retinal periphery; Perifoveolar streaks; Subretinal hyperreflectivity

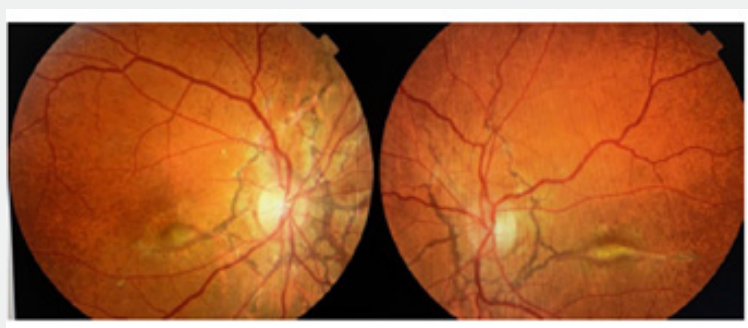

Figure 1: Retinography, bilateral angioid Streaks with macular involvement.

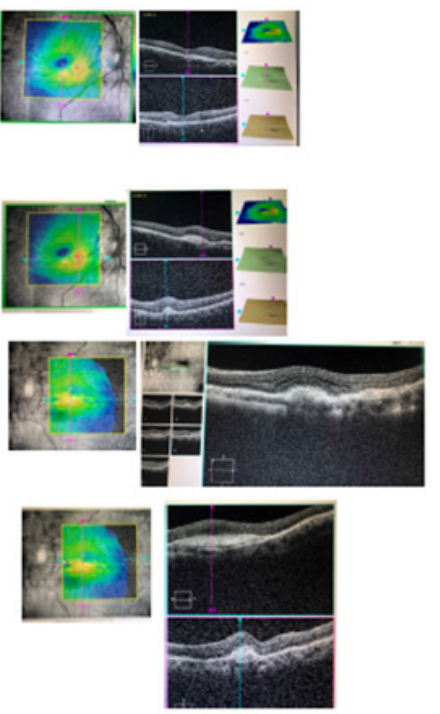

Figure 2: Maculer OCT: bilateral macular involvement. Subfoveal fibrovascular scar on left eye and perifoveolar on right eye. 


\section{JOJ Ophthalmology}

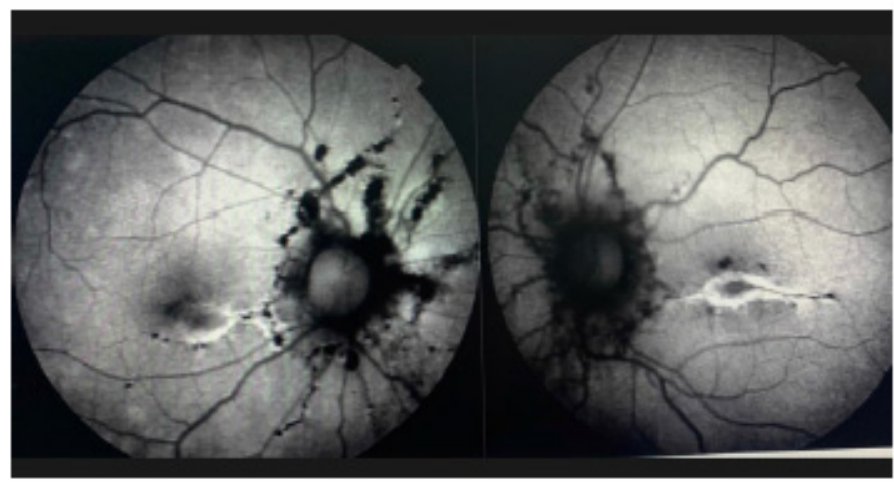

Figure 3: Autofluorescence peripapillary angioid streaks with perifoveolar hyper autofluorescence.

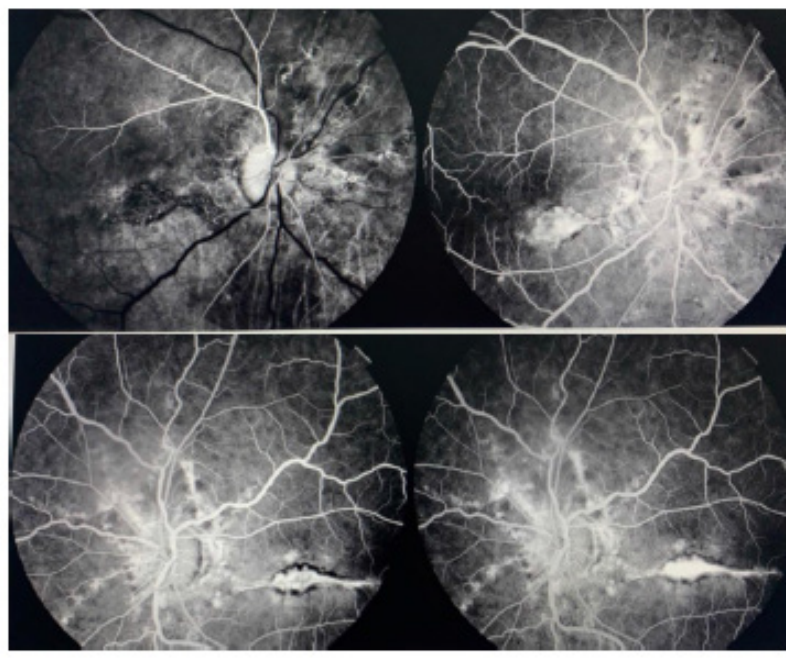

Figure 4: Fluorescein angiography angioid streaks, hyperfluorescence impregnation without diffusion.

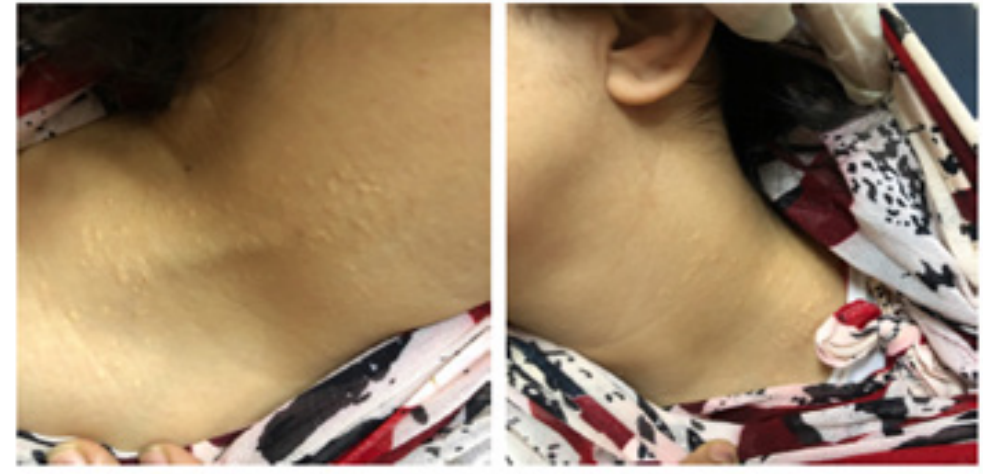

Figure 5: Typical lesions of Pseudoxanthoma Elasticum. 
This work is licensed under Creative Commons Attribution 4.0 License DOI: $10.19080 / J O J O .2020 .08 .555738$

Your next submission with Juniper Publishers
will reach you the below assets
- Quality Editorial service
- Swift Peer Review
- Reprints availability
- E-prints Service
- Manuscript Podcast for convenient understanding
- Global attainment for your research
- Manuscript accessibility in different formats
( Pdf, E-pub, Full Text, Audio)
- Unceasing customer service
Track the below URL for one-step submission
https://juniperpublishers.com/online-submission.php

